\title{
Reflets
}

Revue ontaroise d'intervention sociale et communautaire

\section{Note du rédacteur}

\section{Nérée St-Amand}

Volume 12, numéro 1, 2006

Spiritualité et intervention sociale

URI : https://id.erudit.org/iderudit/013450ar

DOI : https://doi.org/10.7202/013450ar

Aller au sommaire du numéro

Éditeur(s)

Reflets : Revue ontaroise d'intervention sociale et communautaire

ISSN

1203-4576 (imprimé)

1712-8498 (numérique)

Découvrir la revue

Citer cette note

St-Amand, N. (2006). Note du rédacteur. Reflets, 12(1), 219-219.

https://doi.org/10.7202/013450ar

Tous droits réservés (C) Reflets : Revue ontaroise d'intervention sociale et communautaire, 2006



Ce document est protégé par la loi sur le droit d'auteur. L'utilisation des services d'Érudit (y compris la reproduction) est assujettie à sa politique d'utilisation que vous pouvez consulter en ligne.

https://apropos.erudit.org/fr/usagers/politique-dutilisation/ 


\section{Lu pour vous}

Note du rédacteur

Tout au long de ce numéro, nous avons tenté de démontrer que la spiritualité en intervention sociale n'est pas fondée sur quelques préceptes ou recettes. Elle est plutôt le fruit d'une réflexion sur l'existence humaine, sur notre engagement social, sur la conception que nous avons de notre rôle sur terre et sur la contribution possible de notre profession pour faire évoluer les consciences.

Plutôt que d'effectuer en profondeur les quelques recensions habituelles à notre rubrique Lu pour vous, nous vous proposons une variété de ressources, commentées ou pas, pouvant servir d'inspiration à celles et à ceux qui veulent poursuivre leur réflexion sur une spiritualité engagée.

Bonne lecture

Nérée St-Amand 